\title{
PENINGKATAN HASIL BELAJAR SISWA DENGAN METODE PEMBELAJARAN CIRC (COOPERATIVE INTEGRATED READING AND COMPOSITION) PELAJARAN IPS PADA SISWA KELAS VI SD 166325 TEBING TINGGI
}

\author{
Rosdiana Br. Sinaga \\ Surel: rosdiana.sng@gmail.com
}

\begin{abstract}
This purposes of this research is to improve learning result on Social Sciences subject through CIRC method. This classroom action researchconducted by 2 cycles of the four phases: planning, implementation, observation, reflection. The subjects were students fromgrade VI, Elementary Schoold State166325 Tebing Tinggi which amounted to 35 students. This study used a qualitative descriptive analysis technique. The results showed that the use of the CIRC method of social sciences subject can improve student learning result characterized by increased mastery learning students that cycle I (77,14\%), cycle II (91,42\%) and complete learn the clasical equal to $91,42 \%$.
\end{abstract}

Keywords : CIRC, Social Sciences, Learning Outcomes.

\begin{abstract}
ABSTRAK
Penelitian ini bertujuan untuk meningkatkan hasil belajar siswa mata pelajaran IPS melaui metode CIRC. Penelitian tindakan kelas ini dilaksanakan sebanyak 2 siklus dengan empat tahapan yaitu : perencanaan, pelaksanaan, observasi, refleksi. Subjek penelitian ini adalah siswa kelas VI SD Negeri 166325 Tebing Tinggi sebanyak 35 siswa. Penelitian ini menggunakan teknik analisis dekriptif kualitatif. Hasil penelitian menunjukkan bahwa penggunaan metode CIRC pada mata pelajaran IPS dapat meningkatkan hasil belajar siswa yang ditandai dengan peningkatan ketuntasan belajar siswa, yaitu siklus I $(77,14 \%)$, siklus II $(91,42 \%)$, dan dinyatakan berhasil ssecara klasikal 91,42\%.
\end{abstract}

Kata Kunci : CIRC, IPS, Hasil Belajar.

\section{PENDAHULUAN}

Pendidikan pada dasarnya merupakan salah satu usaha untukmengembangkan kualitas sumber daya manusia. SDM yang berkualitas merupakan faktor yang paling berharga dalam pembanguanan yang telah, akan, maupun yang sedang dilaksanakan. Salah satu upaya untuk meningkatkan kualitas sumber daya manusia adalah dengan cara memperbaiki mutu pendidikan.
Pendidikan merupakan suatu pondasi watak, mental dan spiritual manusia sehingga pendidikan suatu bangsa merupakan tolak ukur kualitas bangsa itu sendiri.

Materi pendidikan IPS berasal dari disiplin ilmu-ilmu sosial yang kemudian diorganisasi dan disederhanakan untuk kepentingan pendidikan. Materi pendidikan IPS yang disajikan pada tingkat sekolah dasar tidak menunjukkan label dari masing-masing disiplin ilmu sosial. 


\section{SCHOOL EDUCATION JOURNAL VOLUME 9 NO. 1 JUNI 2019}

Dengan demikian seorang guru yang akan melaksanakan proses pembelajaran IPS harus dibekali dengan sejumlah pemahaman tentang karakteristik pendidikan IPS yang meliputi pengertian dan tujuan pendidikan IPS, landasan filosofis pengembangan kurikulum pendidikan IPS serta disiplin-disiplin ilmu sosial yang dikembangkan dalam pendidikan IPS (Supriatna, dkk, 2010).

Proses pembelajaran pada hakikatnya untuk mengembangkan aktivitas dan kreativitas peserta didik melalui berbagai interaksi dan pengalaman belajar. Namun dalam pelaksanaannya sering tidak disadari bahwa masih banyak kegiatan pembelajaran yang dilaksanakan justru menghambat aktivitas dan kreativitas (Mulyasa, 2006). Berdasarkan hasil observasi dan wawancara peneliti dengan guru kelas VI di SDN 166325 Tebing Tinggi, diperoleh hasil ketuntasan belajar hanya sebanyak 24 siswa dari 35 siswa $(68,57 \%)$. Selain itu pada pembelajaran IPS siswa kurang membaca sehingga kurang aktif untuk melakukan tanya jawab dan mengemukakan pendapatnya, hal ini karena kurangnya pengetahuan siswa sehingga hanya beberapa siswa yang aktif apalagi jika materi yang dibahas mengenai sejarah. Serta dalam kegiatan pembelajarannya jarang menggunakan kelompok belajar jadi siswa belajar secara individu.

Salah satu alternatif yang paling efektif dan efisien diantaranya adalah dengan melakukan penelitian tindakan kelas metode CIRC. Model pembelajaran cooperative integrated reading and composition (CIRC) merupakan model pembelajaran khusus mata pelajaran bahasa Indonesia dalam rangka membaca dan menemukan ide pokok, pokok pikiran atau tema sebuah wacana/kliping (Fogarty, 1991). Model pembelajaran cooperative integrated reading and composition (CIRC) merupakan program komprehensif untuk mengajarkan membaca dan menulis pada kelas sekolah dasar pada tingkat yang lebih tinggi dan juga pada sekolah menengah (Slavin, 2005:16).

Melalui model tersebut pembelajaran IPS yang tadinya dianggap membosankan danbanyak teori dapat dipelajari dengan mudah dan lebih menyenangkan. Model pembelajaran ini akan melatih siswa untuk mampu berpikir kritis dengan membaca untuk menemukan ide pokok dari suatu wacana/materi. Pembelajaran dengan menggunakan model Cooperative Integrated Reading and Composition (CIRC) dilakukan dengan cara membentuk kelompok agar siswa mampu bekerjasama dengan teman satu kelompoknya untuk menemukan suatu ide pokok suatu materi. Setiap anggota kelompok menyampaikan ide/gagasannya mengenai suatu materi yang sedang dibahas dan saling bertukar pendapat untuk menyelesaikan tugas kelompoknya (Christina dan Kristin, 2016).

Salah satu tujuan dari program Cooperative Integrated and 
Reading Composition adalah untuk jauh lebih meningkatkan kesempatan membaca dengan keras dan menerima umpan balik dari kegiatan membaca dengan keras dan menerima umpan balik dari kegiatan membaca mereka dengan membuat para siswa membaca untuk teman satu timnya dan dengan melatih mereka mengenai bagaimana saling merespons kegiatan membaca mereka (Slavin, 2009).

Membaca merupakan suatu kegiatan yang bertujuan memahami makna dan tujuan dari bacaan.Untuk memahami isi bacaan siswa harus mampu menemukan kesatuaan gagasan.Sebuah gagasan dapat ditemui dengan membaca dan memahami kalimat terlebih dahulu (Faisal, 2005: 14). Paragraf adalah rangkaian kalimat yang tersusun secara sistematis dan logis hingga membentuk kesatuan ide. Susunan kalimat yang terdapat dalam paragraf bersatu padu membangun satu pikiran pokok (Nadjua, tt: 121).

\section{Cooperative}

Integrated

Reading and Composition (CIRC) adalah pengajaran kooperatif terpadu membaca dan menulis. Kegiatan pokok dalam CIRC adalah menyelesaikan soal pemecahan masalah meliputi rangkaian kegiatan bersama yang spesifik, yaitu salah satu anggota atau beberapa kelompok membaca soal, membuat prediksi atau menafsirkan isi soal pemecahan masalah (termasuk menuliskan apa yang diketahui, apa yang ditanyakan, dan memisalkan yang ditanyakan dengan suatu variabel), saling membuat ikhtisar/rencana penyelesaian soal pemecahan masalah, menuliskan penyelesaian soal pemecahan masalah secara urut, dan saling merevisi serta mengedit pekerjaan/penyelesaian (Jati, dkk. 2005).

Tujuan dari penelitian ini adalah untuk meningkatkan hasil belajar IPS siswa kelas VI SD Negeri 166325 kota Tebing Tinggi tahun pembelajaran 2017/2018 melalui metode pembelajaran $C I R C$.

\section{METODE PENELITIAN}

Penelitian ini diawali dengan pengajuan judul tentang penelitian yang akan dilaksanakan. Subyek penelitian adalah siswa kelas VI SD Negeri166325 Tebing Tinggi dengan jumlah siswa sebanyak 35 orang dengan 16 orang laki-laki dan 19 orang perempuan. Sumber data yang digunakan adalah siswa dan teman sejawat.

Pada Penelitian tindakan kelas data yang dikumpulkan dapat berbentuk kuantitatif maupun kualitatif. Penelitian tindakan kelas tidak menggunakan uji statistik, tetapi dengan deskriptif. Data kuantitatif yang berupa nilai dianalisis dengan menggunakan analisis deskriptif komparatif yaiu membandingkan nilai tes kondisi awal, nilai tes setelah siklus I dan siklus II yaitu nilai dari hasil ulangan harian siswa kelas VI SD Negeri 166325 Tebing Tinggi pada siklus I dan II. 


\begin{abstract}
Komponen pengajaran strategi pembelajaran CIRC yang sangat data kualitatif yang berupa observasi kegiatan guru, dan sisa serta data kuantitatif yang berupa nilai hasil ulangan harian siswa kelas V.Desain penelitian ini adalah Penelitian Tindakan Kelas (Classroom Action Research). Prosedur PTK mencakup beberapa hal diantaranya: penetapan fokus permasalahan, perencanaan tindakan, pelaksanaan tindakan disertai observasi dan interpretasi, analisis dan refleksi, dan perencanaan tindakan lanjut (bila perlu) (Muslich, 2009).
\end{abstract}

\section{Siklus I}

Dengan bimbingan guru, siswamembentuk kelompok secara heterogen. Guru melakukan pembelajaran di dalam kelas dengan menggunakan panduan perencanaan yang telah dibuat. Pada tahap ini peneliti bertindak sebagai pelaksana kegiatan yang sekaligus juga bertindak sebagai pengamat pelaksanaan tindakan. Guru Membagikan bahan teks bacaan agak pendek dalam bentuk kartu bacaan sekaligus penjelasan yang harus dikerjakan oleh setiapkelompok. Contoh bacaan diambil dari buku paket dan LKS yang menjadi buku pegangan siswa dalam belajar dan guru mengamati dengan seksama cara membaca yang dilakukan oleh siswa. Kemudian Tugas yang harus dikerjakan oleh setiap kelompok, diantaranya menentukan ide pokok pada setiap paragraf dan meringkas bacaan.

\section{Siklus II}

Pada Siklus kedua ini tindakan penelitian hampir sama dengan siklus I namun dilaksankan ke arah yang lebih baik. Kekurangan pada siklus I diperbaiki pada siklus II. Suasana pembelajaran masingmasing kelompok di lingkungan sekolah dikondisikan agar tidak terlalu formal, maksudnya siswa bebas mengemukakan pendapatnya tentang materi ajar sesuai dengan kompetensi dasar yang ingin dicapai.

$$
\text { Pengamatan dilakukan }
$$

peneliti sendiri dan dibantu oleh pengamat dan mencatat proses penerapan teknik pengajaran kolaborasi. Dalam pelaksaan observasi atau lembar cheklist yang berisi tindak mengajar guru dan tindak belajar siswa, selain itu menggunakan dokumentasi berupa foto-foto kegiatan pembelajaran berlangsung, pada tindak mengajar guru sudah bagus menyampaikan pembelajaran sesuai RPP yang telah dibuat, pada tindak belajar siswa sudah aktif dalam mengungkapkan pendapat dan bekerja sama dengan kelompoknya.

$$
\text { Pelaksanaan refleksi }
$$

merupakan hasil observasi/ pengamatan peneliti pada saat melakukan observasi di kelas maupun di lingkungan sekitar sekolah yang bertujuan untuk mengevaluasi hasil tindakan yang telah dilakukan.Kegiatan pada tahap refleksi meliputi kegiatan 
Rosdiana: Peningkatan Hasil Belajar Siswa Dengan Metode ...

menganalisis, memahami dan membuat kesimpulan berdasarkan hasil observasi setiap siklus.Menemukan kelebihan dan kelemahan tindakan perbaikan pembelajaran. Hasil analisis data yang dilaksanakan pada tahap ini akan dipergunakan untuk menemukan kelebihan dan kelemahan diri dalam merancang dan melakukan tindakan sebagai acuan.

Metode pengumpulan data penelitian ini adalah tertulis dan observasi. Penelitian ini dikatakan berhasil apabila siswa telah memperoleh nilai ketuntasan secara klasikal minimal $80 \%$ dari jumlah siswa dengan rumus sebagai berikut:

Persentase Ketuntasan klasikal = Jumlah siswa yang tuntas $\quad$ x $100 \%$ Jumlah siswa yang mengikuti tes

\section{HASIL PENELITIAN DAN PEMBAHASAN}

kelas $\begin{array}{cr}\text { Hasil penelitian tindakan } \\ \text { menunjukkan bahwa }\end{array}$ pengamatan yang dilakukan oleh peneliti pada aktivitas siswa melalui penerapan metode $C I R C$ pada mata pelajaran IPS di kelas VI SD Negeri 166325 Tebing Tinggi. Pada setiap perencanaan setiap siklus dalam setiap pertemuan yaitu menerapkan model pembelajaran kooperatif tipe cooperative integrated reading and composition (CIRC) yang dikembangkan dari analisis kurikulum, silabus, RPP, Lembar observasi aktivitas guru, lembar observasi aktivitas siswa dan hasil UH. Hasil belajar siswa setiap siklusnya dapat dilihat pada Tabel 1 yaitu sebagai berikut:

\section{Tabel 1. Peningkatan Hasil Belajar Siswa Siklus I dan II}

\begin{tabular}{c|c|c|c}
\hline \multirow{2}{*}{ Ket } & \multicolumn{3}{|c}{$\begin{array}{c}\text { Peningkatan Hasil } \\
\text { Belajar }\end{array}$} \\
\cline { 2 - 4 } & $\begin{array}{c}\text { Pra } \\
\text { siklus }\end{array}$ & Sikus I & $\begin{array}{c}\text { Siklus } \\
\text { II }\end{array}$ \\
\hline $\begin{array}{c}\text { Nilai } \bar{x} \\
\text { ulangan } \\
\text { harian }\end{array}$ & 68 & 71 & 72,5 \\
\hline Jumlah & 24 & 27 & 32 \\
\hline siswa & 68,57 & 77,14 & 91,42 \\
\hline $\begin{array}{c}\text { Persen } \\
\text { Ketuntasa } \\
\text { n Belajar } \\
(\%)\end{array}$ & & & \\
\hline \multicolumn{3}{|c|}{ Berdasarkan pengamatan }
\end{tabular}

peneliti dari tindakan pra siklus, siklus I dan siklus II pada Tabel 1 terjadi peningkatan hasil belajar pada jumlah siswa dan persen ketuntasan belajar secara klasikal. Hal ini dapat dilihat dengan peningkatan jumlah siswa dari 24 siswa yang tuntas belajar pada pra siklus menjadi 27 siswa yang tuntas belajar atau sebesar $8,57 \%$. Terjadi peningkatan nilai ulangan rata-rata pada siswa melalui metode pembelajaran CIRC pada siswa kelas VI SD Negeri 166325 Tebing Tinggi.

Pada siklus I nilai rata-rata hasil belajar siswa adalah 71 dan ketuntasan belajar mencapai 77,14\% atau ada 27 siswa dari 34 siswa sudah tuntas belajar. Hasil tersebut menunjukkan bahwa pada siklus pertama secara klasikal siswa belum tuntas belajar, karena siswa yang 
memperoleh nilai $\geq 70$ hanya sebesar 77,14\% lebih kecil dari persentase ketuntasan yang dikehendaki yaitu sebesar $80 \%$.

Pada siklus I masih terdapat kekurangan dalam pembelajaran,antara lain: Siswa masih bingung dalam melaksanakan tugas pembelajaran karena tidak mengikuti pembelajaran dengan baik, Beberapa siswa masih menunjukkan ketidaksiapan dalam mengikuti proses pembelajaran. Hal itu terlihat karena siswa masih banyak yang tidak memperhatikan penjelasan guru. Pembelajaran mayoritas masih merpusat pada guru, guru masih memberikan banyak intruksi pada siswa dalam pembelajaran, Diskusi yang masih belum berjalan secara optimal karena siswa masih ramai sendiri, dan dalam kerjasama kelompok masih banyak siswa yang belum aktif.

Siswa belum terbiasa untuk berdiskusi dan menyampaikan argumennya serta menaggapi pertanyaanlawan bicara terhadap materi yang dibahasdan hanya mengandalkan temannya yang pintar. Namun secara umum proses pembelajaran berlangsung seperti yang direncanakan. Pada perencanaan tindakan pertama ini peneliti menerapkan metode CIRC dengan maksud membantu siswa yang memiliki kemampuan secara heterogen dalam memahami mata pelajaran IPS pada aspek membaca yang difokuskan pada kegiatanmembaca intensif dengan tanpa mengesampingkan cara-cara efektif dalam kegiatan membaca.

Selanjutnya aspek dalam kegiatan inti pembelajaran pada kegiatan inti sudah terlaksana dengan baik, artinya guru mampu melaksanakan tahapan model CIRC secara detail. Namun aspek dalam membuka pelajaran dan menutup pelajaran belum dilaksanakan secara maksimal. Berdasarkan data yang telah diperoleh pada siklus I, menunjukkan bahwa pelakasanaan pem-belajaran yang dilkakukan oleh guru secara keseluruhan belum maksimal, se-hingga perlu dilanjutkan pada siklus II.

Pada siklus II, diperoleh nilai rata-rata hasil belajar siswa adalah 72,5 dan ketuntasan belajar mencapai $91,42 \%$ atau ada 32 siswa dari 35 siswa sudah tuntas belajar. Hasil tersebut menunjukkan bahwa pada siklus kedua secara klasikal siswa sudah tuntas belajar, karena siswa yang memperoleh nilai $\geq 70$ sebesar 91,42\% lebih besar dari persentase ketuntasan yang dikehendaki yaitu sebesar $80 \%$. Pada saat guru menyuruh setiap kelompok untuk memberikan pendapatnya pada topik yang dibahas, hampir semua siswa serius meskipun ada yang kurang fokus dan tidak memperhatikan

\section{Pembahasan}

Secara garis besar kegiatan proses pembelajaran dengan metode pembelajaran Cooperative Integrated Reading adn Composition (CIRC) pada siklus II sudah berhasil. Antusias siswa dalam proses 
pembelajaran pada siklus II sudah sangat baik. Siswa terlihat berantusias dan aktif dari awal proses pembelajaran sampai dengan akhir pembelajaran. Keadaan kelas juga sudah menunjukkan hasil memuaskan. Pada siklus II ini keadaan kelas sudah lebih kondusif daripada sebelumnya. Ketika mengerjakan post test siswa sudah serius dan tidak lagi sibuk bertanya pada temannya.

Tercapainya hasil belajar IPS pada siswa dengan menggunakan model pembelajaran Cooperative Integrated Reading and Composition (CIRC) dikarenakan siswa menjadi lebih termotivasi belajar karena bekerja dalam kelompok (orientasi), pada umumnya membantu siswa yang lemah karena dengan model CIRC ini, persoalan/permasalahan dipecahkan secara berkelompok dengan menggunakan bantuan bahan bacaan berupa artikel (pengenalan konsep), siswa dapat memberikan tanggapannya secara bebas melalui presentasi (publikasi), serta mampu memantapkan pemahaman yang diperoleh selama pembelajaran melalui bentuk pengulangan yang berkaitan dengan materi yang telah dipelajari (penguatan).

Selain dari hasil belajar siswa yang telah memenuhi standaryang telah ditentukan, cara membaca yeng dilakukan oleh siswa juga mengalami peningkatan yang signifikan. Hal ini ditunjukkan ketika peneliti melakukan post tes berupa tes lisan yang menugaskan siswa membaca sebuah bacaan pendek, mereka mampu membaca dengan tanpa menggunakan kebiasaan membaca mereka yang kurang efektif. hampir keseluruhan siswa telah menunjukkan kemampuan mereka dalam melaksanakan kegiatan membaca, diantaranya mampu menjawab pertanyaan berdasarkan isi bacaan, mampu menentukan pokok pikiran paragraf, mampu meringkas bacaan

$$
\text { Penerapan metode }
$$

Cooperetive Integrated Reading and Composition (CIRC) yang berbasis strategi pembelajaran Cooperative Learning banyak menuntut peran aktif siswa baik dalam kerja kelompok maupun yang bersifat individu. Hal ini sesuai dengan pendapat Jati, dkk. (2005) yang menyatakan bahwa Kegiatan pokok dalam CIRC adalah menyelesaikan soal pemecahan masalah meliputi rangkaian kegiatan bersama yang spesifik, yaitu salah satu anggota atau beberapa kelompok membaca soal, membuat prediksi atau menafsirkan isi soal pemecahan masalah, saling membuat ikhtisar/rencana penyelesaian soal pemecahan masalah, menuliskan penyelesaian soal pemecahan masalahsecara urut, dan saling merevisi serta mengedit pekerjaan/penyelesaian.

Berdasarkan hasil yang didapatdari setiap siklus proses pembelajaran yang optimal, hal ini ditunjukkan dengan meningkatnya penguasaan materi dan hasil belajar siswa. Oleh karena itu dapatdisimpulkan bahwa proses 
pembelajaran dengan penerapan Cooperetive Integrated Reading and Composition (CIRC) sangat sesuai dengan mata pelajaran IPS. maka Penelitian Tindakan Kelas (PTK) ini biasdikatakan berhasil karena hasil peningkatan proses pembelajarannya optimal.

\section{SIMPULAN}

Dari hasil temuan penelitian tentang hasil belajar siswa dengan metode eksperimen di kelas VI SD Negeri 166325 Tebing Tinggi berdampak positif dalam meningkatkan hasil belajar siswa. Hal tersebut dapat dilihat dari peningkatan persentase ketuntasan belajar siswa pada pra siklus $(68,57 \%)$, siklus I $(77,14 \%)$ dan siklus II $(91,42 \%)$.

\section{DAFTAR RUJUKAN}

Christina, L dan F. Kristin. 2016. Efektivitas Model Pembelajaran Tipe Group Investigation (GI) dan Cooperative Integrated Reading And Composition (CIRC) Dalam Meningkatkan Kreativitas Berpikir Kritisdan Hasil Belajar IPS Siswa Kelas 4. Jurnal PGSD FKIP Universitas Kristen Satya Wacana.

E. Mulyasa. 2006. Kurikulum yang Disempurnakan. Bandung: PT. Remaja Rosdakarya.

Jati, Y.B., S. Mulyani, B. Hastuti. 2015. Pembelajaran Model Cooperative Integrated Reading And Composition (CIRC) Menggunakan Peta Konsep dan Peta Pikiran Pada Materi Pokok
Sistem Koloid Kelas XI Semester Genap SMA N 1 Sragen Tahun Pelajaran 2012/2013. Jurnal Pendidikan Kimia (JPK), Vol. 4 (1): 104-112. Surakarta: Universitas Sebelas Maret.

Muslih, 2009. Melaksanakan PTK itu Mudah Classroom Action Research. Jakarta: Bumi Aksara.

Slavin, R. E. 2005. Cooperative Learning: Theory, Research, Practice. London: Allymand Bacon.

Supriatna, N., Ade, Sri. 2010. Bahan Belajar Mandiri Pendidikan di SD. Diakses dari http://file.upi.edu/Direktori/DU ALMODES/PENDIDIKAN_IPS_D I_SD/BBM_1.pdf

Suprijono, Agus. 2011. Cooperative Learning Teori dan Aplikasi Faikem. Yogyakarta: Pustaka Belajar. 